\title{
Ecosystem Functions of Microbial Consortia in Sustainable Agriculture
}

\author{
Ana Aguilar-Paredes $1,2, * \mathbb{C}$, Gabriela Valdés ${ }^{1,2}$ and Marco Nuti ${ }^{3}$ (D) \\ 1 Faculty of Sciences, Pontificial Catholic University, Valparaíso 3580000, Chile; gvaldesrodriguez@gmail.com \\ 2 Programme of Soil Biology Restoration, Regional Research and Innovation Centre for Sustainability of \\ Agriculture and Rural Territories-Ceres, Quillota 2260000, Chile \\ 3 Institute of Life Sciences, School of Advanced Studies Sant'Anna, 56127 Pisa, Italy; mn.marconuti@gmail.com \\ * Correspondence: anaaguilarpa@gmail.com; Tel.: +56-979771607
}

Received: 27 October 2020; Accepted: 27 November 2020; Published: 2 December 2020

\begin{abstract}
Knowledge of the agricultural soil microbiota, of the microbial consortia that comprise it, and the promotion of agricultural practices that maintain and encourage them, is a promising way to improve soil quality for sustainable agriculture and to provide food security. Although numerous studies have demonstrated the positive effects of beneficial soil microorganisms on crop yields and quality, the use of microbial consortia in agriculture remains low. Microbial consortia have more properties than an individual microbial inoculum, due to the synergy of the microorganisms that populate them. This review describes the main characteristics, ecosystem functions, crop benefits, and biotechnological applications of microbial consortia composed of arbuscular mycorrhizal fungi (AMF), plant growth-promoting rhizobacteria (PGPR), and Actinobacteria, to promote the restoration of agricultural soils and, consequently, the quality and health of agricultural crops. The aim is to provide knowledge that will contribute to the development of sustainable and sufficiently productive agriculture, which will adapt in a good way to the pace of the growing human population and to climate change.
\end{abstract}

Keywords: microbial consortia; arbuscular mycorrhizas; plant growth-promoting rhizobacteria; Actinobacteria; ecosystem functions; agriculture; sustainability; resilience; multifunctionality; soil microorganism; soil biodiversity

\section{Introduction}

Currently, conventional agriculture and its practices are presented as a major threat to soil vitality [1], causing the alteration of microbial functional diversity and thus worldwide soil degradation, threatening the food chain and safety [2-4]. The intensification of agriculture through excessive and sometimes inappropriate use of chemical pesticides has led to land degradation and environmental pollution in several agroecosystems, which have contaminated water bodies and degraded soils, subsequently leading to the loss of biodiversity by killing beneficial plants, animals, insects, aquatic ecosystem, and other wildlife, and in some cases even poisoning the farm workers [5-7]. Another example is intensive agriculture under plastic covers, which profoundly affects soil quality because it greatly alters the water cycle as well as organic carbon (C) and other nutrient contents. On the one hand, natural rainfall is restricted under plastic tunnels, increasing the salinity of the soil in the upper layers. Likewise, soil acidification caused by the excessive application of minerals and nutrients, frequently used under plastic covers, increases the negative effect on soil quality over time, resulting in lower crop yields $[8,9]$. In addition, the intensive tillage changes the carbon-nitrogen $(\mathrm{C} / \mathrm{N})$ ratio due to loss of soil organic matter through erosion and leaching, causing soil degradation [10]. Nevertheless, 
there is still great potential in soils, which requires adopting strategies that protect them from harmful agricultural practices $[6,11]$.

Although there are multiple strategies for addressing sustainable agriculture and feeding people by reducing environmental impacts, it has been widely reported that promoting agricultural practices that increase biodiversity and the composition of soil microorganisms, such as organic or agro-ecological agriculture, represents an important alternative for obtaining good quality food and improvements in environmental, economic, and social aspects [12-14].

Increased microbial biodiversity stabilizes the functioning of agro-ecosystems and increases the resilience to climate change [15]. Since ancient times, microorganisms have been present in association with plants and animals, giving them multiple benefits in a dynamic equilibrium, which has been attributed to multiple communication systems. Among them are chemical messages at the rhizosphere level [16-18]. These communication systems are fundamental in the agricultural ecosystem, since they regulate all biogeochemical processes in the soil, maintaining its fertility and health. These processes include the decomposition, nutrient cycling, and maintenance of organic matter, control of pathogens, degradation of contaminants, and reduction of greenhouse gases (GHG), which directly affect both crop productivity and the environmental quality [19-21].

In order to benefit from the enormous potential of the soil microbiome, it is necessary to know the distribution and composition of microbial communities in different territories and on different time scales, such as seasonal variations [22]. This information also allows predicting the changes that can be generated in a global climate change scenario. In addition, not knowing the effects of the loss of diversity in specific places and times, it can generate a great impact on ecosystem sustainability and therefore on human well-being [23-25]. The greater the diversity of microorganisms in the soil, the greater the functionality of that soil [26,27], which in turn means food with a higher nutraceutical quality proportional to the soil nutrition and health.

Recently, increasing attention has been given to crops rich in nutrients, minerals, antioxidants, or other metabolites, as they represent a higher food quality and reduce the risk of chronic diseases [28-30]. In this context, new crop practices have emerged that allow obtaining high yields of biomass with a high concentration of beneficial metabolites. The development of biofertilizers made up with beneficial microbial species has emerged [31], as well as the development of microbial consortia of different soil microorganisms [32].

Thus, it is necessary to understand the processes that determine the composition and abundance of soil microorganism communities in order to obtain their multiple benefits in agricultural systems and indirectly in human health. This review aims at describing the main characteristics, ecosystem functions, crop benefits, and biotechnological applications of microbial consortia composed of arbuscular mycorrhizal fungi, plant growth-promoting rhizobacteria, and Actinobacteria, to promote sustainable agriculture and thus the quality and health of agricultural crops.

\section{Discussion}

\subsection{Arbuscular Mycorrhizal Fungi (AMF)}

At the ecological level, mycorrhizal network theory allows the analysis of interactions between plant fungal soil partners as complex multi-species of underground networks [33]. Among the microorganisms present in the soil, AMF are fundamental to soil ecology and agriculture [34]. They form a symbiotic composite association with $93 \%$ of terrestrial plant families, including multiple agricultural crops. They are the oldest known and most prevalent associations in nature $[35,36]$.

AMF belong to the subphylum Glomeromycotina, containing the Archaeosporales, Diversisporales, Glomerales, and Paraglomerales [37], and their symbiosis with plants consists of receiving carbohydrates and lipids from the plant and having specific structures, such as arbuscules and vesicles, that allow the exchange of nutrients with plants at the level of the root bark [38,39]. These have several functions and benefits for plants, which are mainly related to increased nutrient uptake, promoting phosphorus $(\mathrm{P})$, 
iron $(\mathrm{Fe})$, and zinc $(\mathrm{Zn})$ uptake by crops through direct plant-root pathways [40,41], positively affecting crop growth, yield, and reproductive success; thus, reducing fertilizer needs in agricultural systems [42,43].

The establishment of mycorrhizae alters the biological and physicochemical properties of the rhizosphere, leading to the formation of the so-called mycorrhizosphere, where they improve the soil structure, water retention [44], and have an important effect on the induction of systemic resistance to biotic stresses [45].

Conventional agriculture, with its intensive practices, generates a decrease in the diversity of arbuscular mycorrhizae, which means that fewer species of slow colonization potential and rapid sporulation prevail. This leads to a considerable decline in ecosystem functions of arbuscular mycorrhizae $[46,47]$. All the benefits that arbuscular mycorrhizae provide to crops can be used in sustainable agriculture to reduce the environmental impact and obtain food of higher nutritional quality that benefits humans [48,49]. Within these alternatives, organic agriculture is the most widely reported [50-54].

AMF can be an excellent alternative as biofertilizer in agriculture, as shown by multiple laboratory and field studies [31,55]. In highly degraded soils, the application of an external inoculum could be beneficial to overcome situations of biotic or abiotic stress in soils, for which it is necessary to consider the characteristics of the agricultural system to select the AMF species [56,57]. In the same context, it is suggested to apply a mixture of species, since a consortium will always be more effective in soil recovery than a single mycorrhizal species [58]. On the other hand, it has also been proposed to promote communities of native species, which are equally effective; however, in this case we can avoid a possible ecological risk of an external inoculum, for example, by inoculating an aggressive strain that could displace the beneficial autochthonous species [59]. The different benefits of microbial consortia in agricultural crops are presented in Table 1. 
Table 1. Beneficial effects of arbuscular mycorrhizal fungi in agroforestry management.

\begin{tabular}{|c|c|c|c|c|}
\hline AMF Species & Crops & Beneficial Effects & Condition & Reference \\
\hline $\begin{array}{l}\text { Funneliformis mosseae } \\
\text { Rhizophagus irregularis }\end{array}$ & Chickpea (Cicer arietinum L.) & $\begin{array}{l}\text { Increases plant biomass, } \\
\text { production and grain quality }\end{array}$ & Field & [55] \\
\hline Glomus intraradices & Tomato (Solanum Lycopersicum L.) & Improve the yield & Field & [60] \\
\hline Glomus intraradices & Tomato (Solanum Lycopersicum L.) & $\begin{array}{l}\text { Root knot nematode } \\
\text { suppression }\end{array}$ & Greenhouse & {$[61]$} \\
\hline $\begin{array}{c}\text { Rhizophagusintraradices, } \\
\text { Glomus aggregatum, Glomus viscosum, } \\
\text { Glomus etunicatum, } \\
\text { and Glomus claroideum }\end{array}$ & Corn (Zea mays L.) & $\begin{array}{l}\text { Improves crop growth, } \\
\text { yield and grain quality }\end{array}$ & Field & [62] \\
\hline Glomus mosseae, Glomus intraradices & Alfalfa (Medicago sativa L.) & $\begin{array}{c}\text { Increase in glomalin-related soil } \\
\text { protein (GRSP) and stability of } \\
\text { soil aggregate }\end{array}$ & Greenhouse & {$[63]$} \\
\hline AMF natives & Corn (Zea mays L.) & $\begin{array}{l}\text { Increased absorption of } \mathrm{K}, \\
\mathrm{Ca} \text { and } \mathrm{Mg}\end{array}$ & Field & [64] \\
\hline $\begin{array}{l}\text { AMF native consortia: } \\
\text { Glomus mosseae, Glomus fasciculatum, } \\
\text { Glomus etunicatum, } \\
\text { Glomus intraradices, Scutellospora sp. }\end{array}$ & $\begin{array}{l}\text { Green pepper (Capsicum annuum L.), } \\
\text { parsley (Petroselinum crispum (Mill.) Fuss), } \\
\text { carrot (Daucus carota L.), and tomato } \\
\text { (Solanum lycopersicum L.) }\end{array}$ & $\begin{array}{l}\text { Increased plant and root } \\
\text { biomass and yield quality }\end{array}$ & Greenhouse and field & [65] \\
\hline $\begin{array}{c}\text { Glomus fasciculatum, Glomus clarum, } \\
\text { Glomus etunicatum, Glomus } \\
\text { versiforme }\end{array}$ & Long pepper (Piper longum L.) & Improve growth & Greenhouse and field & [66] \\
\hline Glomus intraradices & Potato (Solanum tuberosum L.) & Improve biomass yield & Field & [67] \\
\hline $\begin{array}{l}\text { Glomus intraradices, Glomus mosseae, } \\
\text { Glomusetunicatum }\end{array}$ & Strawberry (Fragaria ananassa Duch.) & Improve productivity & Field & [68] \\
\hline Glomus mosseae, Glomus hoi & Sunflower (Helianthus annuus L.) & Improve biomass yield & Greenhouse & [69] \\
\hline
\end{tabular}




\subsection{Plant Growth-Promoting Rhizobacteria (PGPR)}

The PGPR are a diverse group of bacteria that colonize the plant rhizosphere, showing a positive impact on the environment. The most widely reported bacterial species are of the genera Bacillus, Pseudomonas, Lactobacillus, Acetobacter, Azospirillum, Paenibacillus, Serratia, Burkholderia, Herbaspirillum, and Rhodococcus [70]. The interactions between the plant and PGPR are synergistic, leading to relevant benefits for both the plant crops and the plant microbiome. On the one hand, the plant promotes PGPR establishment through the production of storage substances, such as carbohydrates, organic acids, and minerals, as well as the production of root exudates, which are used by the PGPR for nutrition [71, 72] or as a tool to establish symbiotic interactions, such as the mycorrhizal or dinitrogen-fixing nodulation [16]. The establishment can be endophytic, leading to the colonization of the inner plant structures, including seeds, or to the colonization of the plant intercellular spaces; the establishment can involve also the free-living bacterial cells in the rhizosphere [73,74]. Once established, PGPR show a benefit for plant growth (in terms of yields per hectare of land), crop quality traits, and plant health through direct or indirect mechanisms regulated for biotic and abiotic stress [70,74]. Direct mechanisms promote plant growth by releasing substances stimulating aerial biomass production, root development, and stem elongation. This is achieved through the release or solubilization of phosphates and other nutrients such as potassium $(\mathrm{K})$, zinc $(\mathrm{Zn})$, and silicon $(\mathrm{Si})$; the uptake of biologically fixed di-nitrogen (N2); the chelation of iron ( $\mathrm{Fe})$ and other micronutrients, such as $\mathrm{Zn}$, Boron (B), Calcium (Ca), Magnesium (Mg), and Copper $(\mathrm{Cu})[70,75,76]$; and the increase in available lithospheric oxygen [77]. In addition, PGPR usually synthesize phytohormones, such as gibberellins (gibberellic acid, GA3), auxins (indoleacetic acid, AIA), cytokinins, ethylene, and abscisic acid (ABA) [70,76], which model plant growth and plant cell division. These substances can induce the production of the enzyme 1-aminocyclopropane 1-carboxylate deaminase (ACC), which reduces the level of ethylene in the roots of the crops, thus improving the root length and density [78]

Indirect mechanisms of plant health induction involve modification of the rhizosphere environment and its ecology, inducing systemic resistance and stimulating the innate resilience of the plant (basal genetic resistance) [79]. Among them, PGPR release substances such as siderophores, antibiotics, pigments, organic acids (malic, acetic, citric, oxalic, lactic, formic, gluconic, and 2-keto-gluconic), water-soluble vitamins (niacin, thiamine, and biotin molecules or antioxidants), and volatile organic compounds (monoterpene alcohols) [80]. These substances activate the protection mechanisms of plants against herbivores, insects, and pathogenic microorganisms, and promote the synthesis of physical and chemical barriers against abiotic stress. In turn, they allow PGPR to be more competitive in niche colonization since they can interfere with the quorum detection signal and inhibit the formation of biofilms by pathogenic bacteria [81].

PGPR also promote the synthesis of hydrolytic enzymes (such as glucanases and chitinases) that produce morphological changes in the fungal mycelium, such as the fracture and lysis of the spikes [82], preventing the development of pathogenic fungi. Pseudomonas frederiksbergensi, Bacillus spp., and Planomicrobium spp. have been shown to be effective in improving tolerance to cold and saline stress, which has been linked, e.g., to the activity of antioxidant molecules [73,83-87]; the production of volatile terpenoids by Pseudomonas spp. and Bacillus spp. have increased the protective barriers against soil-borne pathogens in Mentha piperita and Vitis vinifera plants [80,88].

The application of PGPR over time led to relevant benefits in agroforestry management (Table 2). In this context, species of Azospirillum, Pseudomonas, and Paenibacillus have been used for their beneficial effects on the growth and yield of different cereal crops, such as wheat and rice [72,89]. Specifically, Pseudomonas spp. and Paenibacillus spp. have shown a high capacity to make Fe3+ available to plants [89]. Bacillus spp. and Pseudomonas spp. strains have proven to be excellent biofertilizer inoculants, having direct and indirect effects on insect pests associated with agricultural crops and also for the biological control of nematodes [90-92]; the bacterium Pseudomonas frederiksbergensis OS261 has been used as a biostimulant under water- and salt-stress conditions [86]. 
Table 2. Beneficial effects of plant growth-promoting rhizobacteria in agroforestry management.

\begin{tabular}{|c|c|c|c|}
\hline PGPR Species & Crops & Beneficial Effects & Reference \\
\hline Azospirillum spp., Pseudomonas spp. & Rice (Oryza sativa L.) & Increase growth and yield & [72] \\
\hline $\begin{array}{l}\text { Bacillus spp., Pseudomonas spp. } \\
\text { and Azospirillum spp. }\end{array}$ & Seedlings and cuttings & $\begin{array}{l}\text { Increase the germination and the rooting of cuttings, } \\
\text { biocontrol of bacterial wilt and the survival of plants } \\
\text { after transplanting }\end{array}$ & [76] \\
\hline $\begin{array}{l}\text { Pantoea spp., Serratia spp., Acinetobacter spp., } \\
\text { Bacillus spp., Agrobacterium spp., Burkholderia spp., } \\
\text { Pseudomonas spp., Ochrobactrum spp. }\end{array}$ & Soybean (Glycine max L.) & $\begin{array}{l}\text { Production of nodules with high capacity to fix } \\
\text { nitrogen. Important inhibitory activity against } \\
\text { pathogens }\end{array}$ & [82] \\
\hline Pseudomonas frederiksbergensis & Red pepper (Capsicum annuum L.) & Biostimulant under water and salt stress conditions & {$[86]$} \\
\hline Paenibacillus illinoisensis, Bacillus spp. & Peanut (Arachis hypogaea L.) & Increase growth and yield & [89] \\
\hline Pseudomonas spp., Paenibacillus spp. & Calcareous soil & High capacity to make $\mathrm{Fe} 3+$ available to plants & [89] \\
\hline Bacillus spp., Pseudomonas spp. & Wheat (Triticum aestivum L.) & $\begin{array}{l}\text { Excellent biofertilizer inoculants, have direct and } \\
\text { indirect effects on insect pests }\end{array}$ & {$[90,91]$} \\
\hline Bacillus spp., Pseudomonas spp. & Soil & $\begin{array}{l}\text { Control potential of Meloidogyne javanica and } \\
\text { Ditylenchus spp. nematodes }\end{array}$ & [92] \\
\hline
\end{tabular}


In forest nurseries, strains of Bacillus, Pseudomonas, and Azospirillum have allowed an increase in germination and stimulation in the rooting of cuttings, biocontrol of bacterial wilt, and the survival of plants after transplanting, which has been associated with better root development and consequently to an increase in the uptake of nutrients [76].

Another application for legume crops is the production of root nodules, with a high capacity to fix atmospheric nitrogen (N2) in soybean (Glycine max L.). Species of the Pantoea, Serratia, Acinetobacter, Bacillus, Agrobacterium and Burkholderia, Pseudomonas, and Ochrobactrum have been used [82], some of them showing ancillary inhibitory activity against pathogens. However, species such as B. cepacia may also be involved in infection in humans and their use in agriculture is restricted [93]. Therefore, it is important to have a thorough understanding of the safety traits for human health of these microorganisms not having a long history of use before their field application. In the European Union, a recent legislative provision, the so-called Fertilizer Act [94], covers these borderline aspects and makes a clear distinction of what can be marketed as a biofertilizer or as a plant protection product. The placement on the market of the latter category falls under another regulation of the European Parliament and Council [95].

\subsection{Actinobacteria}

Actinobacteria (formerly known as Actinomycetes) are the largest group of prokaryotes and comprise six classes, six orders, and fourteen suborders within which there are both cultivable and non-cultivable species. Bacteria that are present in terrestrial environments can be easily recognized as they generate the characteristic earthy odor that produces an organic compound, known as geosmin $\left(\mathrm{C}_{12} \mathrm{H}_{22} \mathrm{O}\right)$.

Actinobacteria can colonize plant roots endophytically or adhere to epidermal or subcortical root cells. In this context, endophytic bacteria have been described to enter the host plant through root hairs, stomas, wounds, and sprouting hydathodes [96], while in free-living bacteria, structures such as flagella, fimbria, exopolysaccharides, and lipopolysaccharides may facilitate the bacterial attachment to the plant roots [96].

Actinobacteria are classified as Gram-positive, and can be either aerobic or anaerobic, and exhibit various morphological, physiological, and pigmentation traits characteristic of actinobacterial taxa [97-100]. The pigments are commonly known as melanoid polymers and are similar to humic substances present in soil $[99,101]$. These pigments are not necessary for the growth of bacteria but have a significant contribution to improved survival.

In addition to morphological identification, the identification of Actinobacteria has now been facilitated by the use of molecular tools. The genomic organization of Actinobacteria has reported more than 20 sequenced species, which is still a small number. In general, they differ from other bacteria by having a large genome ranging from 1 to $12 \mathrm{Mb}$ in size that is characterized by a high content of $\mathrm{G}+\mathrm{C}$, even higher than $70 \%$, and contain large plasmids [99]. Specifically, it is possible to use 16S rRNA sequence analysis and other preserved sequences to identify some actinobacterial genera $[98,102,103]$. The most referenced actinobacterial genera are Microbispora, Microbacterium, Micrococcus, Micromonospora, Nocardia, Rhodococcus, Streptomyces, Streptosporangium, Streptoverticillium, Arthrobacter, Actinomyces, Corynebacterium, and Frankia. These have been studied principally due to their great capacity to generate diverse bio-active molecules [101].

Actinobacteria are of wide economic and scientific interest, mainly because of their application in human health and agriculture [104], as seen in Table 3. On the one hand, these bacteria are able to synthesize a wide and diverse range of secondary metabolites (more than 10,000 compounds reported) with antimicrobial, antitumor, and anti-inflammatory activity $[101,105]$, and to promote plant growth under abiotic and biotic stress conditions, due to the synthesis of plant growth regulators (phytohormones) and organic acids [97]. In addition, Actinobacteria can fix atmospheric nitrogen, solubilize minerals such as phosphorus [106], produce siderophores [97] to overcome limited nitrogen, iron, and phosphorus conditions [96], and some species can produce antibiotics in situ contributing to maintain plant health.

Actinobacteria also have the ability to synthesis volatile organic compounds that diffuse into the air and soil through the pores acting as chemical agents of communication between species, suppression 
of plant pathogens, formation of biofilms, indicators during differentiation, formation of mycelium, and sporulation and modification of the $\mathrm{pH}$ in the environment [107]. In addition, these can synthesize antimicrobial signaling peptides and quorum sensing regulators, which protect the organism from damage and facilitate interactions with the environment [104].

These bacteria play an important role in the decomposition of plant biomass, playing a vital role in the local ecology and processes, such as the carbon cycle [108]. Actinobacteria have a large reservoir of lytic enzymes, such as proteases, exo-, and endo-glucanases, amylases, lipases, pectinases, and xylanases, that degrade the components of the plant cell wall, facilitating the entry of the cells into the root $[96,97,104,109]$. They also synthesize lytic enzymes such as chitinases, dextranases, cutinases, peroxidases, and laccases, which degrade the cell wall of pathogens and are responsible for their inhibition and growth [110].

More importantly, these bacteria have the capacity to persist in the soil at a high cell density with a high rate of viability, which has led to the study of different applications in agriculture. They act either by suppressing the growth of phytopathogens and promoting growth of important crop plants, i.e., corn, tomato, and banana [111], or the ability to fix nitrogen in non-leguminous plants [97]. Nitrogen-fixing bacteria include members of the Frankia family, Corynebacterium sp., and Pseudonocardia dioxanivorans. Some of them are used as alternative $\mathrm{N}$ fertilizers [97]. Commercial products based on Actinobacteria have been generated, mainly from species of the genus Streptomyces [112], which protect plants against foliar and soil-borne diseases. These organisms can be used as insecticides, herbicides, antifungals, and biocontrol agents, as well as plant growth promoters [99].

\subsection{The Microbial Consortia}

Soil microbes are key ecosystem services provider and drive multifunctional processes, encompassing the interaction of different microbial communities, and the interaction of these with the other soil biota components, i.e., the micro- and mesofauna. Within this complex interconnected network, microorganisms are responsible for maintaining the energy fluxes supporting the entire ecosystem, through the recirculation of available resources [113]. However other organisms form ecological groups in the same environment and share a high multifunctionality in the ecosystem $[22,114]$. Soil microfauna are fundamental to the functionality of the ecosystem and any changes in these key organisms can produce changes at the vegetational, biome, and microbial level [26].

The most relevant groups of microorganisms in the soil are arbuscular mycorrhizal fungi and plant growth-promoting bacteria. These microorganisms together increase $\mathrm{N}_{2}$ fixation and uptake, solubilize P, convert ammonium (which can be chemically bound to clay particles) into soluble, easily assimilable nitrate, protect from other pathogenic microorganisms, and even remediate contaminated soils $[115,116]$ (Figure 1 ).

Arbuscular mycorrhizae, besides being related to plants, are also related to the PGPR in the rhizosphere and to the endobacteria, affecting their activity and generating a synergy in functionality $[117,118]$. The interactions between AMF and soil bacteria influence the expression of fungal genes. The interactions include the adhesion of bacteria to the surface of fungal spores, conidia, and hyphae, the injection of molecules into the fungal spores, the degradation of the fungal cell wall, and the production of volatile substances [119].

The consortia (fungi and bacteria) have multiple applications to sustainable agriculture that have been reported to allow greater nutrient uptake and biocontrol of pathogens, depending on agricultural practices that allow their maintenance [120], such as practices like null or scarce tillage; use of diverse and ideally native crops covers; use of organic amendments as compost; reduction or elimination of external inputs, such as fertilizers, herbicides, and control of pests and diseases; practices that promote agroecology; organic agriculture and smart agriculture to develop a regeneration of soil microbial consortiums; and an ecological intensification of crops [2,12,53]. Likewise, different communities of soil fungi have been detected that affect soil formation or stabilization at the macro- and microaggregate scale through different mechanisms within the physical, biochemical, and biological processes [121,122]. 
Table 3. Beneficial effects of Actinobacteria in agroforestry management.

\begin{tabular}{|c|c|c|c|}
\hline Actinobacteria Species & Crops & Beneficial Effects & Reference \\
\hline Micromonospora spp. & Alfalfa (Medicago sativa L.) & Plant probiotic bacteria & [110] \\
\hline Streptomyces spp. & $\begin{array}{l}\text { Grow on cellulose, hemicellulose } \\
\text { and potentially lignin }\end{array}$ & Biomass degradation & [107] \\
\hline Streptomyces davawensis & Soil & Antibacterial antibiotic roseoflavin & [97] \\
\hline Micromonospora rifamycinica & Mangrove sediment & Antibacterial antibiotic rifamycin & [97] \\
\hline Streptomyces lydicus WYEC 108 & $\begin{array}{l}\text { Grass, ornamentals, vegetables, } \\
\text { and forest species }\end{array}$ & $\begin{array}{l}\text { Biocontrol by soil-borne plant pathogens and } \\
\text { foliar diseases }\end{array}$ & [98] \\
\hline Streptomyces avermitilis & $\begin{array}{l}\text { Ornamentals, vegetables, } \\
\text { and forest species }\end{array}$ & Biocontrol of nematodes and insects & [98] \\
\hline Actinomadura spp. & Vegetables grain & $\begin{array}{l}\text { Bioherbicide/biopesticide producers } \\
\text { 2,4-Dihydro-4-( } \beta \text {-d-ribofuranosyl)-1,2,4 } \\
\text { (3H)-triazol-3-one (herbicide) }\end{array}$ & [99] \\
\hline Streptomyces violaceusniger YCED-9 & Soil & Antifungal agent producing guanidylfungin & [99] \\
\hline Micromonospora lupini Lupac 08 & $\begin{array}{l}\text { Nitrogen-fixing nodule of the } \\
\text { legume Lupinus angustifolius L. }\end{array}$ & Plant growth-promoting bacterium & {$[100]$} \\
\hline $\begin{array}{l}\text { Corynebacterium spp., Pseudonocardia } \\
\text { dioxanivorans, Streptomyces spp., } \\
\text { Micromonospora spp., Streptomyces sp. } \\
\text { Strain MBCN152-1, S. lydicus WYEC } 108\end{array}$ & Vegetables, fruits, and grains & $\begin{array}{l}\text { Plant growth-promoting bacterium and nitrogen } \\
\text { fixation. Biocontrol agent and biofungicide }\end{array}$ & [104] \\
\hline
\end{tabular}


The biotechnological applications of consortia, such as the application of biofertilizers or biostimulants, is justified in agricultural soils of the Mediterranean climate that have less than $3.5 \%$ organic matter, where microorganisms can no longer perform their functions [123]. Considering that in these cases the soil microbiota must be restored with fundamental taxonomic groups or initiators, such as AMF [124], the application of microbial consortia is the preferred approach. These inoculants will have less ecological impact on the ecosystem and therefore on the environment and health [13]. Although further studies at the micro- and mesocosm level, followed by field research, will allow to assess the ability of selected AMF and bacteria to interact with native microorganisms and maintain their beneficial activities [125], the agricultural use of microbial consortia containing bacteria, fungi, and AMF is in its exponential phase [126], based on a range of evidence including wheat [127,128], Mediterranean vegetables [129], lettuce [130], vegetables [131], basil [132], tomato [133], and maize [134].

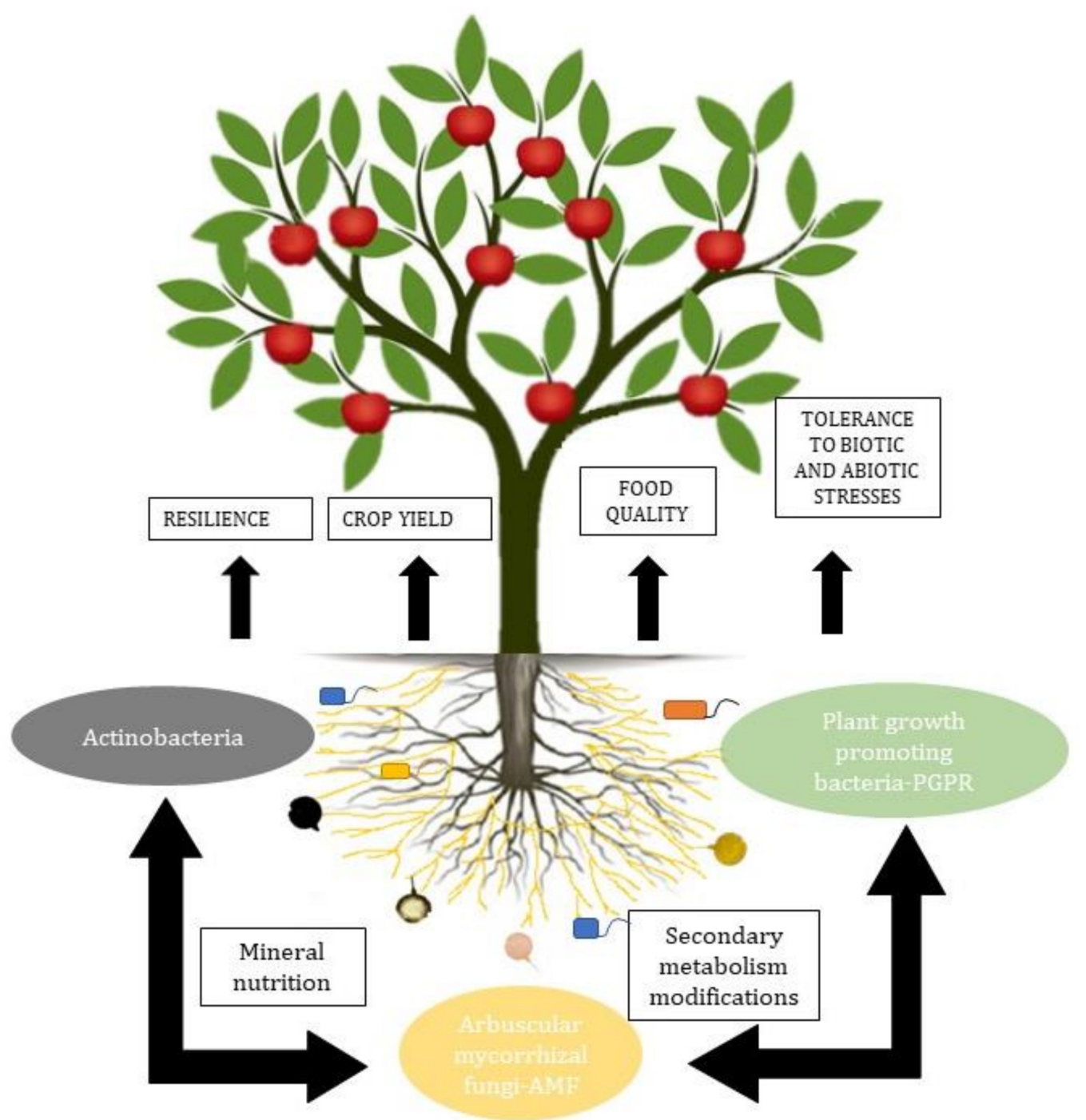

Figure 1. The ecosystem functions of microbial consortia of Actinobacteria, plant growth-promoting rhizobacteria (PGPR), and arbuscular mycorrhizal fungi (AMF) in sustainable agriculture.

Despite the demonstrated benefits produced by soil microorganisms, there is ample space for gaining further insight, especially on arbuscular mycorrhizal fungi, which are crucial for many ecosystem services, such as nutrient cycling and food production. An example is the case of Latin America [135]. In Latin America [136] and Africa, there is a need to focus on soil health and biodiversity among farmers, major agribusinesses, and policy makers, complementing the current productivity paradigm with sustainability and conservation objectives. Therefore, it is vital to describe the 
development of the rhizosphere microbiome in all relevant crops, as microbial communities are deeply affected by agricultural management $[137,138]$. The databases of association between higher plants and mycorrhizal fungi are critical for addressing biogeographic and evolutionary issues [23]. In addition, soil biota is a key factor for the application of appropriate microbial inoculants in the field, but the genotype/genotype interactions between the microbial strain(s) and the crop cultivar(s), e.g., maize, often requires prior screening to obtain the desired results [136]; this is due to the lack of knowledge or neglect of the plant microbiome when selecting the germoplasm for higher productivity [1].

It has been observed that microbial communities are highly sensitive to changes in environmental properties, for example, the geographical location where the type of soil and its $\mathrm{pH}$ play a fundamental role in the distribution of species. In the same way, the climatic conditions and the type of vegetation determine in a dynamic interrelationship the biodiversity of the microbial communities in the different ecosystems $[139,140]$.

Likewise, the specific inoculants of a single group of commercially produced microorganisms represent a small genetic group of fungi and/or bacteria selected to be both generalists and aggressive colonizers [13]. These traits have the potential to affect local communities of microorganisms, which may not be resistant to the introduction of other exogenous species [141]. The role of potentially invasive species in soil ecosystems has received little attention, despite knowledge of the role of soil biodiversity in ecosystem processes.

Currently, the knowledge of the identity of the species that make up a microbial community can be achieved through metagenomics. In order to be able to associate the functionality of certain taxa with the characteristics of crop productivity and resilience, it is necessary to carry on studies including the isolation and cultivation of the species [32]. In Latin America and Africa, there are still many knowledge gaps, where microbial communities are not known or are unidentified taxa $[45,136]$. This represents a problem when predicting changes at the ecosystem level that may be generated in the future, which is relevant in decision-making when designing public policies [23]. To protect the functionalities of terrestrial ecosystems in a productive eco-compatible modern agriculture, it is necessary to include soil microbiota and soil biota in environmental protection and impact assessment policies [22,26].

Climate change with its consequent events, such as droughts, temperature increases, and $\mathrm{CO}_{2}$ increases, generates environmental changes that affect the microbial community and therefore the whole ecosystem. In agriculture, this presents a great challenge since there will be a significant impact on the productivity and resilience of agricultural systems $[12,13]$. Currently, different strategies are being developed to abort this issue, one of them being the Climatic Smart Agriculture, which seeks to develop a sustainable food system; to increase crop productivity and quality; and to reduce the impacts of climate change, through the adaptation and building of crop resilience, as well as conserving and increasing carbon stocks in soils and reducing GHGs [27].

Some examples for smart agriculture are the reported associations of the bacteria Rahnella aquatilis, which improves organic phosphorus solubilization, with the mycorrhizal fungus Rhizophagus irregularis. The association between the rhizospheric yeast fungi Cryptococcus flavus or Candida railenensis and the arbuscular mycorrhizal fungus Rhizophagus irregularis promotes root growth in corn plants [142]; in turn, the Brettanomyces naardensis yeast's association with fungi reduces the incidence of the pathogen Macrophomina phaseolina in sunflower plants; in addition, this association significantly improves the plant's growth parameters, such as plant height, dry weight, and number of leaves [143]. It has also been reported that consortia between filamentous fungi and PGPR stimulate the growth and yield of substances produced by plants, such as essential oils [144].

\section{Conclusive Remarks}

The biotechnological application of microorganisms, either through the selection and inoculation of specific microbial strains or just by promoting the activity of naturally occurring microbes, holds a great potential for sustainable agriculture, as these innovative agronomic practices have the capacity 
to replace conventional agricultural practices. Beneficial microbes are multifunctional, with effects ranging from protection from pathogens to reduction of drought, stimulation of nutrient uptake, and can reproduce and be self-sufficient. In addition, microbe management can promote systems that are resilient to climate change.

When thinking about the formulation of microbial consortia, we should consider functional taxa of various species that are effective and compatible with other soil organisms, where they will be applied according to their geographical and climatic conditions. It is expected that future research related to sustainable agriculture will focus on the importance of soil (micro) biota, focusing on both the morphology of cultivable microorganisms and the metagenomics of all species found in the soil, in order to formulate distribution maps that will allow us to make informed decisions on the effect of agricultural practices on (micro) biomes.

Author Contributions: All the authors provided equal contribution to the review. All authors have read and agreed to the published version of the manuscript.

Funding: This research was financially supported by the CONICYT (ANID) I + D Ciencia y territorio 2019. NO. R19F10005 and by the Project PSR 2014-2020, Measure 16.2 PS-GO 2017-FERTIBIO-CUP ARTEA 828090.

Acknowledgments: All the authors acknowledge the Centre CERES and Sant'Anna School for providing the facilities and tools to accomplish this work.

Conflicts of Interest: The authors declare that they have no known competing financial interests or personal relationships that could have appeared to influence the work reported in this review.

\section{Abbreviations}

$\begin{array}{ll}\text { GHG } & \text { greenhouse gases } \\ \text { AMF } & \text { arbuscular mycorrhizal fungi } \\ \text { PGPR } & \text { plant growth promoting bacteria } \\ \text { gibberellic acid, GA3 } & \text { gibberellins } \\ \text { indolacetic acid, AIA } & \text { auxins } \\ \text { ABA } & \text { abscisic acid } \\ \text { ACC } & \text { enzyme 1-aminocyclopropane 1-carboxylate deaminase }\end{array}$

\section{References}

1. Porter, S.S.; Sachs, J.L. Agriculture and the Disruption of Plant-Microbial Symbiosis. Trends Ecol. Evol. 2020, 35, 426-439. [CrossRef]

2. Hartman, K.; Van Der Heijden, M.G.A.; Wittwer, R.A.; Banerjee, S.; Walser, J.-C.; Schlaeppi, K. Cropping practices manipulate abundance patterns of root and soil microbiome members paving the way to smart farming. Microbiome 2018, 6, 1-14. [CrossRef]

3. Springmann, M.; Clark, M.; Mason-D'Croz, D.; Wiebe, K.; Bodirsky, B.L.; Lassaletta, L.; De Vries, W.; Vermeulen, S.J.; Herrero, M.; Carlson, K.M.; et al. Options for keeping the food system within environmental limits. Nature 2018, 562, 519-525. [CrossRef] [PubMed]

4. Stavi, I.; Lal, R. Achieving Zero Net Land Degradation: Challenges and opportunities. J. Arid. Environ. 2015, 112, 44-51. [CrossRef]

5. Kughur, P.G.; Otene, V.; Audu, O.C. Effects of intensive agricultural production on the environment in benue state, Nigeria. IOSR J. Agric. Vet. Sci. (IOSR-JAVS) 2015, 8, 7-11. [CrossRef]

6. Gomiero, T.; Pimentel, D.; Paoletti, M.G. Environmental Impact of Different Agricultural Management Practices: Conventional vs. Organic Agriculture. Crit. Rev. Plant Sci. 2011, 30, 95-124. [CrossRef]

7. Devarinti, S.R. Natural Farming: Eco-Friendly and Sustainable? Agrotechnology 2016, 5, 1-3. [CrossRef]

8. Bonanomi, G.; D’Ascoli, R.; Antignani, V.; Capodilupo, M.; Cozzolino, L.; Marzaioli, R.; Puopolo, G.; Rutigliano, F.A.; Scelza, R.; Scotti, R.; et al. Assessing soil quality under intensive cultivation and tree orchards in Southern Italy. Appl. Soil Ecol. 2011, 47, 184-194. [CrossRef]

9. Chen, Q.; Zhang, X.; Zhang, H.; Christie, P.; Li, X.; Horlacher, D.; Liebig, H.-P. Evaluation of current fertilizer practice and soil fertility in vegetable production in the Beijing region. Nutr. Cycl. Agroecosyst. 2004, 69, 51-58. [CrossRef] 
10. Purwanto, B.H.; Alam, S. Impact of intensive agricultural management on carbon and nitrogen dynamics in the humid tropics. Soil Sci. Plant Nutr. 2019, 66, 50-59. [CrossRef]

11. Sá, J.C.D.M.; Lal, R.; Cerri, C.C.; Lorenz, K.; Hungria, M.; Carvalho, P.C.D.F. Low-carbon agriculture in South America to mitigate global climate change and advance food security. Environ. Int. 2017, 98, 102-112. [CrossRef] [PubMed]

12. Altieri, M.A. Agroecology the Science of Sustainable Agricultura, 2nd ed.; CRC Press: Boca Raton, FL, USA, 2018; p. 448. [CrossRef]

13. Bender, S.F.; Wagg, C.; Van Der Heijden, M.G.A. An Underground Revolution: Biodiversity and Soil Ecological Engineering for Agricultural Sustainability. Trends Ecol. Evol. 2016, 31, 440-452. [CrossRef] [PubMed]

14. Eyhorn, F.; Muller, A.; Reganold, J.P.; Frison, E.; Herren, H.R.; Luttikholt, L.; Mueller, A.; Sanders, J.; Scialabba, N.E.-H.; Seufert, V.; et al. Sustainability in global agriculture driven by organic farming. Nat. Sustain. 2019, 2, 253-255. [CrossRef]

15. Isbell, F.; Craven, D.; Connolly, J.; Loreau, M.; Schmid, B.; Beierkuhnlein, C.; Bezemer, T.M.; Bonin, C.L.; Bruelheide, H.; De Luca, E.; et al. Biodiversity increases the resistance of ecosystem productivity to climate extremes. Nat. Cell Biol. 2015, 526, 574-577. [CrossRef] [PubMed]

16. Oldroyd, G.E.D. Speak, friend, and enter: Signalling systems that promote beneficial symbiotic associations in plants. Nat. Rev. Microbiol. 2013, 11, 252-263. [CrossRef]

17. Bassler, B.L.; Losick, R. Bacterially Speaking. Cell 2006, 125, 237-246. [CrossRef]

18. Brameyer, S.; Bode, H.B.; Heermann, R. Languages and dialects: Bacterial communication beyond homoserine lactones. Trends Microbiol. 2015, 23, 521-523. [CrossRef]

19. Bardgett, R.D.; Van Der Putten, W.H. Belowground biodiversity and ecosystem functioning. Nat. Cell Biol. 2014, 515, 505-511. [CrossRef]

20. Mendes, R.; Garbeva, P.; Raaijmakers, J.M. The rhizosphere microbiome: Significance of plant beneficial, plant pathogenic, and human pathogenic microorganisms. FEMS Microbiol. Rev. 2013, 37, 634-663. [CrossRef]

21. Philippot, L.; Raaijmakers, J.M.; Lemanceau, P.; Van Der Putten, W.H. Going back to the roots: The microbial ecology of the rhizosphere. Nat. Rev. Mircobiol. 2013, 11, 789-799. [CrossRef]

22. Delgado-Baquerizo, M.; Maestre, F.T.; Reich, P.B.; Jeffries, T.C.; Gaitan, J.J.; Encinar, D.; Berdugo, M.; Campbell, C.D.; Singh, B.K. Microbial diversity drives multifunctionality in terrestrial ecosystems. Nat. Commun. 2016, 7, 1-8. [CrossRef] [PubMed]

23. Chu, H.; Gao, G.-F.; Ma, Y.; Fan, K.; Delgado-Baquerizo, M. Soil Microbial Biogeography in a Changing World: Recent Advances and Future Perspectives. mSystems 2020, 5, 1-12. [CrossRef] [PubMed]

24. Kuzyakov, Y.; Blagodatskaya, E. Microbial hotspots and hot moments in soil: Concept \& review. Soil Biol. Biochem. 2015, 83, 184-199. [CrossRef]

25. Wagg, C.; Bender, S.F.; Widmer, F.; Van Der Heijden, M.G.A. Soil biodiversity and soil community composition determine ecosystem multifunctionality. Proc. Natl. Acad. Sci. USA 2014, 111, 5266-5270. [CrossRef]

26. Delgado-Baquerizo, M.; Reich, P.B.; Trivedi, C.; Eldridge, D.J.; Abades, S.; Alfaro, F.D.; Bastida, F.; Berhe, A.A.; Cutler, N.A.; Gallardo, A.; et al. Multiple elements of soil biodiversity drive ecosystem functions across biomes. Nat. Ecol. Evol. 2020, 4, 210-220. [CrossRef]

27. Das, S.; Ho, A.; Kim, P.J. Editorial: Role of Microbes in Climate Smart Agriculture. Front. Microbiol. 2019, 10, 2756. [CrossRef]

28. Rillig, M.C.; Lehmann, A.; Lehmann, J.; Camenzind, T.; Rauh, C. Soil Biodiversity Effects from Field to Fork. Trends Plant Sci. 2018, 23, 17-24. [CrossRef]

29. Ochoa-Hueso, R. Global Change and the Soil Microbiome: A Human-Health Perspective. Front. Ecol. Evol. 2017, 5, 71. [CrossRef]

30. Wall, D.H.; Nielsen, U.N.; Six, J. Soil biodiversity and human health. Nat. Cell Biol. 2015, 528, 69-76. [CrossRef]

31. Berruti, A.; Lumini, E.; Balestrini, R.; Bianciotto, V. Arbuscular Mycorrhizal Fungi as Natural Biofertilizers: Let's Benefit from Past Successes. Front. Microbiol. 2016, 6, 1559. [CrossRef]

32. Kong, Z.; Hart, M.; Liu, H. Paving the Way From the Lab to the Field: Using Synthetic Microbial Consortia to Produce High-Quality Crops. Front. Plant Sci. 2018, 9, 1467. [CrossRef] [PubMed]

33. Van Der Heijden, M.G.A.; Martin, F.M.; Selosse, M.-A.; Sanders, I.R. Mycorrhizal ecology and evolution: The past, the present, and the future. New Phytol. 2015, 205, 1406-1423. [CrossRef] [PubMed] 
34. Thirkell, T.J.; Charters, M.D.; Elliott, A.J.; Sait, S.M.; Field, K.J. Are mycorrhizal fungi our sustainable saviours? Considerations for achieving food security. J. Ecol. 2017, 105, 921-929. [CrossRef]

35. Brundrett, M.C.; Tedersoo, L. Evolutionary history of mycorrhizal symbioses and global host plant diversity. New Phytol. 2018, 220, 1108-1115. [CrossRef] [PubMed]

36. Smith, S.E.; Read, D.J. Mycorrhizal Symbiosis, 2nd ed.; Academic Press: Cambridge, MA, USA; Elsevier: London, UK, 2008; p. 800. [CrossRef]

37. Spatafora, J.W.; Chang, Y.; Benny, G.L.; Lazarus, K.; Smith, M.E.; Berbee, M.L.; Bonito, G.; Corradi, N.; Grigoriev, I.; Gryganskyi, A.; et al. A phylum-level phylogenetic classification of zygomycete fungi based on genome-scale data. Mycologia 2016, 108, 1028-1046. [CrossRef] [PubMed]

38. Rich, M.K.; Nouri, E.; Courty, P.-E.; Reinhardt, D. Diet of Arbuscular Mycorrhizal Fungi: Bread and Butter? Trends Plant Sci. 2017, 22, 652-660. [CrossRef] [PubMed]

39. Parniske, M. Arbuscular mycorrhiza: The mother of plant root endosymbioses. Nat. Rev. Microbiol. 2008, 6, 763-775. [CrossRef]

40. Smith, S.E.; Jakobsen, I.; Grønlund, M.; Smith, F.A. Roles of Arbuscular Mycorrhizas in Plant Phosphorus Nutrition: Interactions between Pathways of Phosphorus Uptake in Arbuscular Mycorrhizal Roots Have Important Implications for Understanding and Manipulating Plant Phosphorus Acquisition. Plant Physiol. 2011, 156, 1050-1057. [CrossRef]

41. Coccina, A.; Cavagnaro, T.R.; Pellegrino, E.; Ercoli, L.; McLaughlin, M.J.; Watts-Williams, S.J. The mycorrhizal pathway of zinc uptake contributes to zinc accumulation in barley and wheat grain. BMC Plant Biol. 2019, 19, 1-14. [CrossRef]

42. Azcón-Aguilar, C.; Barea, J. Nutrient cycling in the mycorrhizosphere. J. Soil Sci. Plant Nutr. 2015, 15, 372-396. [CrossRef]

43. Cavagnaro, T.R.; Bender, S.F.; Asghari, H.R.; Van Der Heijden, M.G. The role of arbuscular mycorrhizas in reducing soil nutrient loss. Trends Plant Sci. 2015, 20, 283-290. [CrossRef]

44. Augé, R.M. Arbuscular mycorrhizae and soil/plant water relations. Can. J. Soil Sci. 2004, 84, 373-381. [CrossRef]

45. Cameron, D.D.; Neal, A.L.; Van Wees, S.C.; Ton, J. Mycorrhiza-induced resistance: More than the sum of its parts? Trends Plant Sci. 2013, 18, 539-545. [CrossRef]

46. Oehl, F.; Sieverding, E.; Ineichen, K.; Mäder, P.; Boller, T.; Wiemken, A. Impact of Land Use Intensity on the Species Diversity of Arbuscular Mycorrhizal Fungi in Agroecosystems of Central Europe. Appl. Environ. Microbiol. 2003, 69, 2816-2824. [CrossRef]

47. Oehl, F.; Sieverding, E.; Dubois, D.; Ineichen, K.; Boller, T.; Wiemken, A. Impact of long-term conventional and organic farming on the diversity of arbuscular mycorrhizal fungi. Oecologia 2004, 138, 574-583. [CrossRef]

48. Turrini, A.; Avio, L.; Giovannetti, M.; Agnolucci, M. Functional Complementarity of Arbuscular Mycorrhizal Fungi and Associated Microbiota: The Challenge of Translational Research. Front. Plant Sci. 2018, 9, 1407. [CrossRef]

49. Gianinazzi, S.; Gollotte, A.; Binet, M.-N.; Van Tuinen, D.; Redecker, D.; Wipf, D. Agroecology: The key role of arbuscular mycorrhizas in ecosystem services. Mycorrhiza 2010, 20, 519-530. [CrossRef]

50. Silva-Flores, P.; Aguilar, A.; Dibán, M.J.; Mujica, M.I. Chapter 14 Mycorrhizas in the South American Mediterranean-Type Ecosystem: Chilean Matorral. In Mycorrhizal Fungi in South America, 1st ed.; Pagano, M., Lugo, M., Eds.; Springer: Cham, Switzerland, 2019; pp. 277-294. [CrossRef]

51. Säle, V.; Aguilera, P.; Laczko, E.; Mäder, P.; Berner, A.; Zihlmann, U.; Van Der Heijden, M.G.A.; Oehl, F. Impact of conservation tillage and organic farming on the diversity of arbuscular mycorrhizal fungi. Soil Biol. Biochem. 2015, 84, 38-52. [CrossRef]

52. Bedini, S.; Avio, L.; Sbrana, C.; Turrini, A.; Migliorini, P.; Vazzana, C.; Giovannetti, M. Mycorrhizal activity and diversity in a long-term organic Mediterranean agroecosystem. Biol. Fertil. Soils 2013, 49, 781-790. [CrossRef]

53. Verbruggen, E.; Röling, W.F.M.; Gamper, H.A.; Kowalchuk, G.A.; Verhoef, H.A.; Van Der Heijden, M.G.A. Positive effects of organic farming on below-ground mutualists: Large-scale comparison of mycorrhizal fungal communities in agricultural soils. New Phytol. 2010, 186, 968-979. [CrossRef]

54. Gosling, P.; Hodge, A.; Goodlass, G.; Bending, G. Arbuscular mycorrhizal fungi and organic farming. Agric. Ecosyst. Environ. 2006, 113, 17-35. [CrossRef]

55. Pellegrino, E.; Bedini, S. Enhancing ecosystem services in sustainable agriculture: Biofertilization and biofortification of chickpea (Cicer arietinum L.) by arbuscular mycorrhizal fungi. Soil Biol. Biochem. 2014, 68, 429-439. [CrossRef] 
56. Rang-Jin, X.; Franken, P.; Schneider, C.; Schwarz, D.; Giovannetti, M.; Agnolucci, M.; De Pascale, S.; Bonini, P.; Colla, G. Arbuscular mycorrhizal fungi act as biostimulants in horticultural crops. Sci. Hortic. 2015, 196, 91-108. [CrossRef]

57. Verbruggen, E.; Van Der Heijden, M.G.A.; Rillig, M.C.; Kiers, E.T. Mycorrhizal fungal establishment in agricultural soils: Factors determining inoculation success. New Phytol. 2013, 197, 1104-1109. [CrossRef]

58. Crossay, T.; Majorel, C.; Redecker, D.; Gensous, S.; Medevielle, V.; Durrieu, G.; Cavaloc, Y.; Amir, H. Is a mixture of arbuscular mycorrhizal fungi better for plant growth than single-species inoculants? Mycorrhiza 2019, 29, 325-339. [CrossRef]

59. Hart, M.M.; Antunes, P.M.; Chaudhary, V.B.; Abbott, L.K. Fungal inoculants in the field: Is the reward greater than the risk? Funct. Ecol. 2018, 32, 126-135. [CrossRef]

60. Makus, D. Mycorrhizal inoculation of tomato and onion transplants improves earliness. Acta Hortic. 2004, 631, 275-281. [CrossRef]

61. Lax, P.; Becerra, A.G.; Soteras, F.; Cabello, M.; Doucet, M.E. Effect of the arbuscular mycorrhizal fungus Glomus intraradices on the false root-knot nematode Nacobbus aberrans in tomato plants. Biol. Fertil. Soils 2011, 47, 591-597. [CrossRef]

62. Berta, G.; Copetta, A.; Gamalero, E.; Bona, E.; Cesaro, P.; Scarafoni, A.; D'Agostino, G. Maize development and grain quality are differentially affected by mycorrhizal fungi and a growth-promoting pseudomonad in the field. Mycorrhiza 2013, 24, 161-170. [CrossRef]

63. Bedini, S.; Pellegrino, E.; Avio, L.; Pellegrini, S.; Bazzoffi, P.; Argese, E.; Giovannetti, M. Changes in soil aggregation and glomalin-related soil protein content as affected by the arbuscular mycorrhizal fungal species Glomus mosseae and Glomus intraradices. Soil Biol. Biochem. 2009, 41, 1491-1496. [CrossRef]

64. Liu, A.; Hamel, C.; Elmi, A.; Costa, C.A.V.; Ma, B.; Smith, D.L. Concentrations of K, Ca and Mg in maize colonized by arbuscular mycorrhizal fungi under field conditions. Can. J. Soil Sci. 2002, 82, 272-278. [CrossRef]

65. Regvar, M.; Vogel-Mikuš, K.; Ševerkar, T. Effect of AMF inoculum from field isolates on the yield of green pepper, parsley, carrot, and tomato. Folia Geobot. 2003, 38, 223-234. [CrossRef]

66. Singh, R.K.; Gogoi, P. Augmented growth of long pepper in response to arbuscular mycorrhizal inoculation. J. For. Res. 2012, 23, 339-344. [CrossRef]

67. Douds, D.D.; Nagahashi, G.; Reider, C.; Hepperly, P.R. Inoculation with Arbuscular Mycorrhizal Fungi Increases the Yield of Potatoes in a High P Soil. Biol. Agric. Hortic. 2007, 25, 67-78. [CrossRef]

68. Stewart, L.I.; Hamel, C.; Hogue, R.; Moutoglis, P. Response of strawberry to inoculation with arbuscular mycorrhizal fungi under very high soil phosphorus conditions. Mycorrhiza 2005, 15, 612-619. [CrossRef]

69. Gholamhoseini, M.; Ghalavand, A.; Dolatabadian, A.; Jamshidi, E.; Khodaei-Joghan, A. Effects of arbuscular mycorrhizal inoculation on growth, yield, nutrient uptake and irrigation water productivity of sunflowers grown under drought stress. Agric. Water Manag. 2013, 117, 106-114. [CrossRef]

70. Backer, R.; Rokem, J.S.; Ilangumaran, G.; Lamont, J.; Praslickova, D.; Ricci, E.; Subramanian, S.; Smith, D.L. Plant Growth-Promoting Rhizobacteria: Context, Mechanisms of Action, and Roadmap to Commercialization of Biostimulants for Sustainable Agriculture. Front. Plant Sci. 2018, 9, 1473. [CrossRef]

71. Hassan, M.K.; McInroy, J.A.; Kloepper, J.W. The Interactions of Rhizodeposits with Plant Growth-Promoting Rhizobacteria in the Rhizosphere: A Review. Agriculture 2019, 9, 142. [CrossRef]

72. Braga, L.F.; De Oliveira, F.A.; Couto, E.A.P.D.; Santos, K.F.D.N.; Ferreira, E.P.D.B.; Martin-Didonet, C.C.G. Polyphasic characterization of bacteria obtained from upland rice cultivated in Cerrado soil. Braz. J. Microbiol. 2018, 49, 20-28. [CrossRef]

73. Abbas, R.; Rasul, S.; Aslam, K.; Baber, M.; Shahid, M.; Mubeen, F.; Naqqash, T. Halotolerant PGPR: A hope for cultivation of saline soils. J. King Saud Univ. Sci. 2019, 31, 1195-1201. [CrossRef]

74. Akram, M.S.; Shahid, M.; Tariq, M.; Azeem, M.; Javed, M.T.; Saleem, S.; Riaz, S. Deciphering Staphylococcus sciuri SAT-17 Mediated Anti-oxidative Defense Mechanisms and Growth Modulations in Salt Stressed Maize (Zea mays L.). Front. Microbiol. 2016, 7, 867. [CrossRef]

75. Rijavec, T.; Lapanje, A. Hydrogen Cyanide in the Rhizosphere: Not Suppressing Plant Pathogens, but Rather Regulating Availability of Phosphate. Front. Microbiol. 2016, 7, 1785. [CrossRef]

76. Angulo, V.C.; Sanfuentes, E.A.; Rodríguez, F.; Sossa, K.E. Caracterización de rizobacterias promotoras de crecimiento en plántulas de Eucalyptus nitens. Rev. Argent. Microbiol. 2014, 46, 338-347. [CrossRef] 
77. Rehman, F.; Pervez, A.; Khattak, B.N.; Ahmad, R. Plant Growth Promoting Rhizobacteria Impact onTypha latifoliaandPhragmites australisGrowth and Dissolved Oxygen. CLEAN Soil Air Water 2018, 46. [CrossRef]

78. Penrose, D.M.; Glick, B.R. Levels of ACC and related compounds in exudate and extracts of canola seeds treated with ACC deaminase-containing plant growth-promoting bacteria. Can. J. Microbiol. 2001, 47, 368-372. [CrossRef]

79. Takishita, Y.; Charron, J.-B.; Smith, D.L. Biocontrol Rhizobacterium Pseudomonas sp. 23S Induces Systemic Resistance in Tomato (Solanum lycopersicum L.) Against Bacterial Canker Clavibacter michiganensis subsp. michiganensis. Front. Microbiol. 2018, 9, 2119. [CrossRef]

80. Cappellari, L.D.R.; Chiappero, J.; Santoro, M.V.; Giordano, W.; Banchio, E. Inducing phenolic production and volatile organic compounds emission by inoculating Mentha piperita with plant growth-promoting rhizobacteria. Sci. Hortic. 2017, 220, 193-198. [CrossRef]

81. Bhattacharyya, P.N.; Jha, D.K. Plant growth-promoting rhizobacteria (PGPR): Emergence in agriculture. World J. Microbiol. Biotechnol. 2012, 28, 1327-1350. [CrossRef]

82. Zhao, L.; Xu, Y.; Lai, X. Antagonistic endophytic bacteria associated with nodules of soybean (Glycine max L.) and plant growth-promoting properties. Braz. J. Microbiol. 2018, 49, 269-278. [CrossRef]

83. Sapre, S.; Gontia-Mishra, I.; Tiwari, S. Klebsiella sp. confers enhanced tolerance to salinity and plant growth promotion in oat seedlings (Avena sativa). Microbiol. Res. 2018, 206, 25-32. [CrossRef]

84. Shahid, M.; Akram, M.; Khan, M.A.; Zubair, M.; Shah, S.M.; Ismail, M.; Shabir, G.; Basheer, S.; Aslam, K.; Tariq, M. A phytobeneficial strainPlanomicrobiumsp. MSSA-10 triggered oxidative stress responsive mechanisms and regulated the growth of pea plants under induced saline environment. J. Appl. Microbiol. 2018, 124, 1566-1579. [CrossRef]

85. Shahid, M.; Shahid, M.; Hussain, S.; Shahzad, T.; Haider, M.Z.; Noman, M.; Mushtaq, A.; Fatima, Q.; Ahmed, T.; Mustafa, G. Enzymatic detoxification of azo dyes by a multifarious Bacillus sp. strain MR-1/2-bearing plant growth-promoting characteristics. 3 Biotech 2018, 8, 425. [CrossRef]

86. Chatterjee, P.; Samaddar, S.; Anandham, R.; Kang, Y.; Kim, K.; Selvakumar, G.; Sa, T. Beneficial Soil Bacterium Pseudomonas frederiksbergensis OS261 Augments Salt Tolerance and Promotes Red Pepper Plant Growth. Front. Plant Sci. 2017, 8, 705. [CrossRef]

87. Khan, M.Y.; Zahir, Z.A.; Asghar, H.N.; Waraich, E.A. Preliminary investigations on selection of synergistic halotolerant plant growth promoting rhizobacteria for inducing salinity tolerance in wheat. Pak. J. Bot. 2017, $49,1541-1551$.

88. Salomon, M.V.; Purpora, R.; Bottini, R.; Piccoli, P.N. Rhizosphere associated bacteria trigger accumulation of terpenes in leaves of Vitis vinifera L. cv. Malbec that protect cells against reactive oxygen species. Plant Physiol. Biochem. 2016, 106, 295-304. [CrossRef]

89. Liu, D.; Yang, Q.; Ge, K.; Hu, X.; Qi, G.; Du, B.; Liu, K.; Ding, Y. Promotion of iron nutrition and growth on peanut by Paenibacillus illinoisensis and Bacillus sp. strains in calcareous soil. Braz. J. Microbiol. 2017, 48, 656-670. [CrossRef]

90. Naeem, M.; Aslam, Z.; Khaliq, A.; Ahmed, J.N.; Nawaz, A.; Hussain, M. Plant growth promoting rhizobacteria reduce aphid population and enhance the productivity of bread wheat. Braz. J. Microbiol. 2018, 49, 9-14. [CrossRef]

91. Hussain, M.; Asgher, Z.; Tahir, M.; Ijaz, M.; Shahid, M.; Ali, H.; Sattar, A. Bacteria in Combination with Fertilizers Improve Growth, Productivity and Net Returns of Wheat (Triticum aestivum L.). Pak. J. Agric. Sci. 2016, 53, 633-645. [CrossRef]

92. Turatto, M.F.; Dourado, F.D.S.; Zilli, J.E.; Botelho, G.R. Control potential of Meloidogyne javanica and Ditylenchus spp. using fluorescent Pseudomonas and Bacillus spp. Braz. J. Microbiol. 2017, 49, 54-58. [CrossRef]

93. Rojas-Rojas, F.U.; López-Sánchez, D.; Meza-Radilla, G.; Méndez-Canarios, A.; Ibarra, J.A.; Santos, P.E.-D.L. El controvertido complejo Burkholderia cepacia, un grupo de especies promotoras del crecimiento vegetal y patógenas de plantas, animales y humanos. Rev. Argent. Microbiol. 2019, 51, 84-92. [CrossRef]

94. Regolamento (UE) 2019/1009 del Parlamento Europeo e del Consiglio del 5 Giugno 2019 che Stabilisce Norme Relative Alla Messa a Disposizione sul Mercato di Prodotti Fertilizzanti dell'UE, Che Modifica i Regolamenti (CE) n. 1069/2009 e (CE) n. 1107/2009 e che Abroga Il Regolamento (CE) n. 2003/2003. Gazzetta Ufficiale dell'UE del 25.6.2019. Available online: https://eur-lex.europa.eu/legal-content/IT/TXT/PDF/?uri=CELEX: 32019R1009\&from =HU (accessed on 2 September 2020). 
95. Regolamento (CE) N. 1107/2009 del Parlamento Europeo e del Consig lio del 21 Ottobre 2009 Relativo All'immissione sul Mercato dei Prodotti Fitosanitari e che Abroga le Direttive del Consiglio 79/117/CEE e 91/414/CEE. Gazzetta Ufficiale dell’U.E. del 24.11.2009. Available online: https:/eur-lex.europa.eu/eli/reg/ 2009/1107/oj (accessed on 2 September 2020).

96. Kandel, S.L.; Joubert, P.M.; Doty, S.L. Bacterial Endophyte Colonization and Distribution within Plants. Microorganisms 2017, 5, 77. [CrossRef]

97. Bhatti, A.A.; Haq, S.; Bhat, R.A. Actinomycetes benefaction role in soil and plant health. Microb. Pathog. 2017, 111, 458-467. [CrossRef]

98. Sousa, J.A.D.J.; Olivares, F.L. Plant growth promotion by streptomycetes: Ecophysiology, mechanisms and applications. Chem. Biol. Technol. Agric. 2016, 3, 1-12. [CrossRef]

99. Barka, E.A.; Vatsa, P.; Sanchez, L.; Gaveau-Vaillant, N.; Jacquard, C.; Klenk, H.-P.; Clément, C.; Ouhdouch, Y.; Van Wezel, G.P. Taxonomy, Physiology, and Natural Products of Actinobacteria. Microbiol. Mol. Biol. Rev. 2016, 80, 1-43. [CrossRef]

100. Trujillo, M.E.; Bacigalupe, R.; Pujic, P.; Igarashi, Y.; Benito, P.; Riesco, R.; Médigue, C.; Normand, P. Genome Features of the Endophytic Actinobacterium Micromonospora lupini Strain Lupac 08: On the Process of Adaptation to an Endophytic Life Style? PLOS ONE 2014, 9, e108522. [CrossRef]

101. Manivasagan, P.; Venkatesan, J.; Sivakumar, K.; Kim, S.-K. Pharmaceutically active secondary metabolites of marine actinobacteria. Microbiol. Res. 2014, 169, 262-278. [CrossRef]

102. Girard, G.; Traag, B.A.; Sangal, V.; Mascini, N.; Hoskisson, P.A.; Goodfellow, M.; Van Wezel, G.P. A novel taxonomic marker that discriminates between morphologically complex actinomycetes. Open Biol. 2013, 3, 130073. [CrossRef]

103. Verma, M.; Lal, D.; Kaur, J.; Saxena, A.; Kaur, J.; Anand, S.; Lal, R. Phylogenetic analyses of phylum Actinobacteria based on whole genome sequences. Res. Microbiol. 2013, 164, 718-728. [CrossRef]

104. Salwan, R.; Sharma, V. Molecular and biotechnological aspects of secondary metabolites in actinobacteria. Microbiol. Res. 2020, 231, 126374. [CrossRef]

105. Gomes, K.M.; Duarte, R.S.; Bastos, M.D.C.D.F. Lantibiotics produced by Actinobacteria and their potential applications (a review). Microbiology 2017, 163, 109-121. [CrossRef]

106. Bouizgarne, B.; Aouamar, A.A.B. Diversity of Plant Associated Actinobacteria. In Bacterial Diversity in Sustainable Agriculture, 1st ed.; Maheswari, D.K., Ed.; Springer: Cham, Switzerland, 2014; pp. 41-99.

107. Lewin, G.R.; Carlos, C.; Chevrette, M.G.; Horn, H.A.; McDonald, B.R.; Stankey, R.J.; Fox, B.G.; Currie, C.R. Evolution and Ecology of Actinobacteria and Their Bioenergy Applications. Annu. Rev. Microbiol. 2016, 70, 235-254. [CrossRef] [PubMed]

108. Wei, Y.; Wu, D.; Wei, D.; Zhao, Y.; Wu, J.; Xie, X.; Zhang, R.; Wei, Z. Improved lignocellulose-degrading performance during straw composting from diverse sources with actinomycetes inoculation by regulating the key enzyme activities. Bioresour. Technol. 2019, 271, 66-74. [CrossRef] [PubMed]

109. Mukhtar, S.; Zaheer, A.; Aiysha, D.; Malik, K.A.; Mehnaz, S. Actinomycetes: A Source of Industrially Important Enzymes. J. Proteom. Bioinform. 2017, 10, 316-319. [CrossRef]

110. Martínez-Hidalgo, P.; Galindo-Villardón, P.; Trujillo, M.E.; Igual, J.M.; Martínez-Molina, E. Micromonospora from nitrogen fixing nodules of alfalfa (Medicago sativa L.). A new promising Plant Probiotic Bacteria. Sci. Rep. 2014, 4, 6389. [CrossRef]

111. Vurukonda, S.S.K.P.; Giovanardi, D.; Stefani, E. Plant Growth Promoting and Biocontrol Activity of Streptomyces spp. as Endophytes. Int. J. Mol. Sci. 2018, 19, 952. [CrossRef]

112. Fierer, N. Embracing the unknown: Disentangling the complexities of the soil microbiome. Nat. Rev. Genet. 2017, 15, 579-590. [CrossRef]

113. Wagg, C.; Schlaeppi, K.; Banerjee, S.; Kuramae, E.E.; Van Der Heijden, M.G.A. Fungal-bacterial diversity and microbiome complexity predict ecosystem functioning. Nat. Commun. 2019, 10, 1-10. [CrossRef]

114. Richardson, A.E.; Barea, J.-M.; McNeill, A.M.; Prigent-Combaret, C. Acquisition of phosphorus and nitrogen in the rhizosphere and plant growth promotion by microorganisms. Plant Soil 2009, 321, 305-339. [CrossRef]

115. Barea, J.M.; Pozo, M.J.; Azcón, R.; Azcón-Aguilar, C. Microbial co-operation in the rhizosphere. J. Exp. Bot. 2005, 56, 1761-1778. [CrossRef]

116. Avio, L.; Turrini, A.; Giovannetti, M.; Sbrana, C. Designing the Ideotype Mycorrhizal Symbionts for the Production of Healthy Food. Front. Plant Sci. 2018, 9, 1-19. [CrossRef] 
117. Bonfante, P.; Anca, I.-A. Plants, Mycorrhizal Fungi, and Bacteria: A Network of Interactions. Annu. Rev. Microbiol. 2009, 63, 363-383. [CrossRef] [PubMed]

118. Miransari, M. Contribution of arbuscular mycorrhizal symbiosis to plant growth under different types of soil stress. Plant Biol. 2010, 12, 563-569. [CrossRef] [PubMed]

119. Johansson, J.F.; Paul, L.R.; Finlay, R.D. Microbial interactions in the mycorrhizosphere and their significance for sustainable agriculture. FEMS Microbiol. Ecol. 2004, 48, 1-13. [CrossRef] [PubMed]

120. Rillig, M.C.; Mummey, D.L. Mycorrhizas and soil structure. New Phytol. 2006, 171, 41-53. [CrossRef] [PubMed]

121. Piazza, G.; Pellegrino, E.; Moscatelli, M.C.; Ercoli, L. Long-term conservation tillage and nitrogen fertilization effects on soil aggregate distribution, nutrient stocks and enzymatic activities in bulk soil and occluded microaggregates. Soil Tillage Res. 2020, 196, 104482. [CrossRef]

122. Lynch, J.M.; Benedetti, A.; Insam, H.; Nuti, M.P.; Smalla, K.; Torsvik, V.; Nannipieri, P. Microbial diversity in soil: Ecological theories, the contribution of molecular techniques and the impact of transgenic plants and transgenic microorganisms. Biol. Fertil. Soils 2004, 40, 363-385. [CrossRef]

123. Sosa-Hernández, M.A.; Leifheit, E.F.; Ingraffia, R.; Rillig, M.C. Subsoil Arbuscular Mycorrhizal Fungi for Sustainability and Climate-Smart Agriculture: A Solution Right Under Our Feet? Front. Microbiol. 2019, 10, 744. [CrossRef]

124. Giovannini, L.; Palla, M.; Agnolucci, M.; Avio, L.; Sbrana, C.; Turrini, A.; Giovannetti, M. Arbuscular Mycorrhizal Fungi and Associated Microbiota as Plant Biostimulants: Research Strategies for the Selection of the Best Performing Inocula. Agronomy 2020, 10, 106. [CrossRef]

125. Rouphael, Y.; Colla, G. Editorial: Biostimulants in Agriculture. Front. Plant Sci. 2020, 11, 40. [CrossRef]

126. Migliorini, P.; Torri, L.; Whittaker, A.; Moschini, V.; Benedettelli, S.; Masoero, G. Old and new common wheat (Triticum aestivum L.) varieties in organic: Connecting agronomic, microorganism, phytochemical and bread sensory characteristics. J. Food Agric. Environ. 2018, 16, 22-27. [CrossRef]

127. Cortivo, C.D.; Ferrari, M.; Visioli, G.; Lauro, M.; Fornasier, F.; Barion, G.; Panozzo, A.; Vamerali, T. Effects of Seed-Applied Biofertilizers on Rhizosphere Biodiversity and Growth of Common Wheat (Triticum aestivum L.) in the Field. Front. Plant Sci. 2020, 11, 72. [CrossRef] [PubMed]

128. Raiola, A.; Tenore, G.C.; Petito, R.; Ciampaglia, R.; Ritieni, A. Improving of nutraceutical features of many important mediterranean vegetables by inoculation with a new commercial product. Curr. Pharm. Biotechnol. 2015, 16, 738-746. [CrossRef] [PubMed]

129. Rouphael, Y.; Cardarelli, M.; Bonini, P.; Colla, G. Synergistic Action of a Microbial-based Biostimulant and a Plant Derived-Protein Hydrolysate Enhances Lettuce Tolerance to Alkalinity and Salinity. Front. Plant Sci. 2017, 8, 131. [CrossRef] [PubMed]

130. Colla, G.; Rouphael, Y.; Di Mattia, E.; El-Nakhel, C.; Cardarelli, M. Co-inoculation of Glomus intraradicesand Trichoderma atrovirideacts as a biostimulant to promote growth, yield and nutrient uptake of vegetable crops. J. Sci. Food Agric. 2015, 95, 1706-1715. [CrossRef] [PubMed]

131. Battini, F.; Turrini, A.; Sgherri, C.; Malorgio, F.; Quartacci, M.F. Dual inoculation with AMF and associated bacteria improves nutraceutical value of sweet basil grown under commercial conditions. Agrochimica 2016, 60, 81-99. [CrossRef]

132. Baldi, E.; Toselli, M.; Masoero, G.; Nuti, M. Organic and Symbiotic Fertilization of Tomato Plants Monitored by Litterbag-NIRS and Foliar-NIRS Rapid Spectroscopic Methods. J. Agron. Res. 2020, 3, 9-26. [CrossRef]

133. Akhtar, N.; Naveed, M.; Khalid, M.; Ahmad, N.; Rizwan, M.; Siddique, S. Effect of bacterial consortia on growth and yield of maize grown in Fusarium infested soil. Soil Environ. 2018, 37, 35-44. [CrossRef]

134. Cameron, E.K.; Martins, I.S.; Lavelle, P.; Mathieu, J.; Tedersoo, L.; Gottschall, F.; Guerra, C.A.; Hines, J.; Patoine, G.; Siebert, J.; et al. Global gaps in soil biodiversity data. Nat. Ecol. Evol. 2018, 2, 1042-1043. [CrossRef]

135. Marín, C.; Bueno, C.G. A Systematic Review of South American and European Mycorrhizal Research: Is there a Need for Scientific Symbiosis? In Mycorrhizal Fungi in South America, 1st ed.; Pagano, M., Lugo, M., Eds.; Springer: Cham, Switzerland, 2019; pp. 97-110.

136. Wall, L.G.; Gabbarini, L.A.; Ferrari, A.E.; Frene, J.P.; Covelli, J.; Reyna, D.; Robledo, N.B. Changes of paradigms in agriculture soil microbiology and new challenges in microbial ecology. Acta Oecol. 2019, 95, 68-73. [CrossRef]

137. Piazza, G.; Ercoli, L.; Nuti, M.; Pellegrino, E. Interaction Between Conservation Tillage and Nitrogen Fertilization Shapes Prokaryotic and Fungal Diversity at Different Soil Depths: Evidence From a 23-Year Field Experiment in the Mediterranean Area. Front. Microbiol. 2019, 10, 2047. [CrossRef] 
138. Volpato, S.; Masoero, G.; Giovannetti, G.; Nuti, M. Arbuscular Mycorrhizal Biofertilizers Sources in the Potato (Solanum Tuberosum) Plant show Interactions with Cultivars on Yield and Litter-bags Spectral Features. J. Agron. Res. 2020, 2, 9-17. [CrossRef]

139. Liu, H.; Brettell, L.E.; Qiu, Z.; Singh, B.K. Microbiome-Mediated Stress Resistance in Plants. Trends Plant Sci. 2020, 25, 733-743. [CrossRef]

140. Ramirez, K.S.; Snoek, L.B.; Koorem, K.; Geisen, S.; Bloem, L.J.; Hooven, F.T.; Kostenko, O.; Krigas, N.; Manrubia, M.; Caković, D.; et al. Range-expansion effects on the belowground plant microbiome. Nat. Ecol. Evol. 2019, 3, 604-611. [CrossRef]

141. Machado, A.A.D.S.; Valyi, K.; Rillig, M.C. Potential Environmental Impacts of an "Underground Revolution": A Response to Bender et al. Trends Ecol. Evol. 2017, 32, 8-10. [CrossRef]

142. Sarabia, M.; Cazares, S.; González-Rodríguez, A.; Mora, F.; Carreón-Abud, Y.; Larsen, J. Plant growth promotion traits of rhizosphere yeasts and their response to soil characteristics and crop cycle in maize agroecosystems. Rhizosphere 2018, 6, 67-73. [CrossRef]

143. Nafady, N.A.; Hashem, M.; Hassan, E.A.; Ahmed, H.A.; Alamri, S.A. The combined effect of arbuscular mycorrhizae and plant-growth-promoting yeast improves sunflower defense against Macrophomina phaseolina diseases. Biol. Control 2019, 138, 104049. [CrossRef]

144. Singh, S.; Tripathi, A.; Maji, D.; Awasthi, A.; Vajpayee, P.; Kalra, A. Evaluating the potential of combined inoculation of Trichoderma harzianum and Brevibacterium halotolerans for increased growth and oil yield in Mentha arvensis under greenhouse and field conditions. Ind. Crop. Prod. 2019, 131, 173-181. [CrossRef]

Publisher's Note: MDPI stays neutral with regard to jurisdictional claims in published maps and institutional affiliations. 